\title{
PENGARUH STORE ATMOSPHERE TERHADAP KEPUTUSAN PEMBELIAN KONSUMEN PADA TOSERBA TERBIT KUNINGAN (Survey pada Konsumen Toserba Terbit Kuningan)
}

\author{
Yessi Mariana Usti \\ Lili Karmela fitriani
}

\section{Program Studi Manajemen Fakultas Ekonomi Universitas Kuningan}

\author{
marianausti@yahoo.co.id \\ lili@uniku.ac.id
}

\begin{abstract}
Abstrack
This research arises the decline in sales during the period of last 5 years on Toserba Terbit who are on the road Sudirman No.02 Kuningan. Based on the results of previous studies, the consumer purchasing decision can be influenced by Store Atmosphere such Exterior, General Interior, Store Layout and Interior Display. But it turns out there is a contradiction with the condition that occurs in the field, namely the decline in consumer purchasing decisions on Toserba Terbit Kuningan. It can be shown by the decline in sales during the period of last 5 years.

The purpose of this study was to determine the influence of variables such as Store Atmosphere Exterior, General Interior, Store Layout and Interior Display the consumer buying decision at Toserba Terbit Kuningan is conducted a survey on consumers of Toserba Terbit Kuningan.

In this study, data was collected by using questionnaire tools. Its population is consumers of Toserba Terbit Kuningan. The method used in this research is descriptive analysis method with a sample size of 100 respondents. Sample selection technique uses accidental sampling. To Acquire variable data of X1 (Exterior), X2 (General Interior), X3 (Store Layout), X4 (Interior Display) and Y (Purchase Decision), the study uses the instrument test, the classical assumption test, coefficient determination test, multiple regression analysis, hypothesis testing through $t$ test. The results show that Exterior, General Interior, Store Layout and Interior Display have positive and significant impact on the Consumer Purchasing Decision of Toserba Terbit Kuningan.
\end{abstract}

Keywords: Exterior, General Interior, Store Layout, Interior Display and Consumer Purchase Decision 
Indonesian Journal Of Strategic Management Vol 1, Issue 1, Februari 2018

\section{PENDAHULUAN}

Bisnis eceran atau Bisnis ritel, merupakan bisnis yang menghidupi banyak orang dan memberi keuntungan bagi sebagian orang lainnya. Indonesia sendiri mendapat bantuan besar dari sektor perdagangan eceran saat krisis moneter melanda Indonesia di akhir tahun 1997. Menurut Asosiasi ep swalayan/self sevice). Oleh karena itu bisnis ritel di Indonesia berkembang begitu pesat.

Bisnis ritel semakin meningkat khususnya di Kabupaten Kuningan, terdapat beberapa bisnis ritel terbesar di Kuningan, yaitu : Toserba Surya, Toserba Yogya, Toserba Griya dan Toserba Terbit. Banyaknya jumlah pasar swalayan yang ada di Kuningan menyebabkan konsumen mempunyai banyak alternative pilihan untuk berbelanja. Kesuksesan dalam persaingan akan dapat dipenuhi apabila perusahaan bisa menciptakan dan mempertahankan konsumen. Untuk mencapai tujuan tersebut maka perusahaan memerlukan berbagai upaya agar tujuan yang telah direncanakan dapat tercapai. Karena banyaknya perusahaan ritel di Kuningan yang berdiri, memicu perusahaan dibidang ini untuk memaksimalkan dan mempertahankan atau meningkatkan perusahaan agar bisa bersaing dengan perusahaan sejenis lainnya.

Keputusan pembelian oleh konsumen untuk melakukan pembelian suatu produk diawali oleh adanya kesadaran atas pemenuhan kebutuhan dan keinginan. Sesudah konsumen dipengaruhi oleh tingkat pentingnya kebutuhan tersebut serta sumber daya yang dimiliki oleh konsumen, pada akhirnya konsumen akan melakukan proses keputusan pembelian. Dimana pengambilan keputusan konsumen mempunyai berbagai pengaruh luar yang
Printed ISSN 2614-5391, e-ISSN 2614-2406 https://journal.uniku.ac.id/index.php/ijsm

Perusahaan Ritel Indonesia (Aprindo), Hingga saat ini, bisnis ritel masih menjadi salah satu sumber penghasilan bagi sebagian besar masyarakat Indonesia. Indonesia dengan jumlah penduduk sekitar 237 juta jiwa merupakan pasar potensial bagi bisnis ritel modern (toko berkons

berlaku sebagai pencarian informasi mengenai produk tertentu yang mempengaruhi nilai-nilai, sikap, dan perilaku konsumen.

Store Atmosphere (suasana toko) menurut Christina Whidya Utami (2006:238) adalah desain lingkungan melalui komunikasi visual, pencahayaan, warna, musik, wangiwangian dapat merangsang respon emosional sehingga memberikan persepsi pelanggan untuk mempengaruhi pelanggan dalam membeli barang. Berman dan Evans (2010:02) membagi elemen-elemen store atmosphere kedalam empat elemen, yaitu: Eksterior, General interior, Store Layout dan Interior Display.

Banyaknya supermarket dan mini market yang semakin merajalela di Kuningan membuat Toserba Terbit semakin memiliki persaingan dari masalah store atmosphere atau suasana toko terhadap keputusan pembelian konsumen, sehingga membuat Toserba Terbit ini mengalami penurunan penjualan.

\section{LANDASAN TEORI \\ Store Atmosphere}

Menurut Kotler dan Keller (2009) Store atmosphere merupakan unsur senjata lain yang dimiliki toko. Setiap toko mempunyai tata letak fisik yang memudahkan atau menyulitkan pembeli untuk berputar-putar didalamnya. Setiap toko mempunyai penampilan. Toko harus membentuk suasana terencana yang sesuai dengan pasar sasarannya dan 
Indonesian Journal Of Strategic Management Vol 1, Issue 1, Februari 2018

yang dapat menarik konsumen untuk membeli.

Store atmosphere (suasana toko) menurut Christina Whidya Utami (2006:238) adalah desain lingkungan melalui komunikasi visual, pencahayaan, warna, musik, dan wangiwangian untuk merangsang respon emosional terhadap persepsi pelanggan serta mempengaruhi pelanggan dalam membeli barang.

\section{Elemen-Elemen Store Atmosphere}

Store Atmosphere memiliki elemenelemen yang semuanya berpengaruh terhadap suasana toko yang ingin diciptakan. Elemen-elemen store atmosphere terdiri dari exterior, general interior, store layout, dan interior displays.

\section{Eksterior}

Menurut Berman dan Evans (2007;545548) Eksterior sebuah toko mempunyai pengaruh yang kuat terhadap image toko dan harus direncanakan secara matang. Konsumen terkadang menilai sebuah toko dari bagian depannya. Bagian depan sebuah toko merupakan keseluruhan physical eksterior dari sebuah toko. Yang termasuk dalam eksterior adalah pintu masuk, etalase, teras, papan nama toko, dan konstruksi material lainnya.

\section{General Interior}

Menurut Berman dan Evans (2001:604) mendefinisikan bahwa General Interior yaitu berbagai motif konsumen memasuki toko, hendaknya memperoleh kesan yang menyenangkan. Kesan ini dapat diciptakan misalnya dengan warna dinding toko yang menarik, musik yang diperdengarkan, serta aroma/bau dan udara di dalam toko.

\section{3. $\quad$ Store Layout}

Menurut Berman dan Evans (2007:552552) Perencanaan store layout meliputi penataan penempatan ruang untuk mengisi luas lantai yang tersedia,
Printed ISSN 2614-5391, e-ISSN 2614-2406 https://journal.uniku.ac.id/index.php/ijsm

mengklasifikasikan produk yang akan ditawarkan, pengaturan lalu lintas di dalam toko, pengaturan lebar ruang yang dibutuhkan, pemetaan ruangan toko, dan menyusun produk yang ditawarkan secara individu.

\section{Interior Display}

Menurut Berman dan Evans (2001:604) mendefinisikan Interior Display sangat penting bagi suasana toko karena memberikan informasi kepada konsumen. Tujuan utamanya adalah untuk meningkatkan penjualan dan laba bagi toko.

\section{Keputusan Pembelian Konsumen}

Schiffman dan Kanuk (2010:29) keputusan pembelian adalah sebagai pemilihan suatu tindakan dari dua atau lebih pilihan alternatif. Seorang konsumen yang hendak melakukan pilihan maka ia harus memiliki pilihan alternatif.

Menurut Kotler dan Amstrong (2015) tahap-tahap pengambilan keputusan konsumen adalah sebagai berikut:

1. Pengenalan Masalah merupakan tahap pertama proses keputusan pembelian dimana konsumen mengenali permasalahan atau kebutuhan adanya perbedaan antara keadaan nyata dan sejumlah keadaan yang diinginkan.

2. Pencari Informasi merupakan tahap proses pengambilan keputusan pembeli dimana konsumen tergerak untuk mencari informasi tambahan, konsumen mungkin sekedar meningkatkan perhatian atau mungkin pula mencari informasi secara aktif.

3. Pengevaluasian Alternatif merupakan tahap proses keputusan pembeli dimana konsumen menggunakan informasi untuk mengevaluasi berbagai merek alternatif di dalam serangkaian pilihan.

4. Keputusan Pembelian merupakan tahap proses keputusan 
Indonesian Journal Of Strategic Management Vol 1, Issue 1, Februari 2018

dimana konsumen secara aktual melakukan pembelian produk. Dalam keputusan pembelian, konsumen seringkali melibatkan lebih dari dua pihak dalam proses pembelian.

5. Perilaku setelah pembelian merupakan tahap proses keputusan pembeli konsumen melakukan tindakan lebih lanjut setelah pembelian berdasarkan kepuasan atau ketidakpuasan mereka.

\section{Paradigma Penelitian}

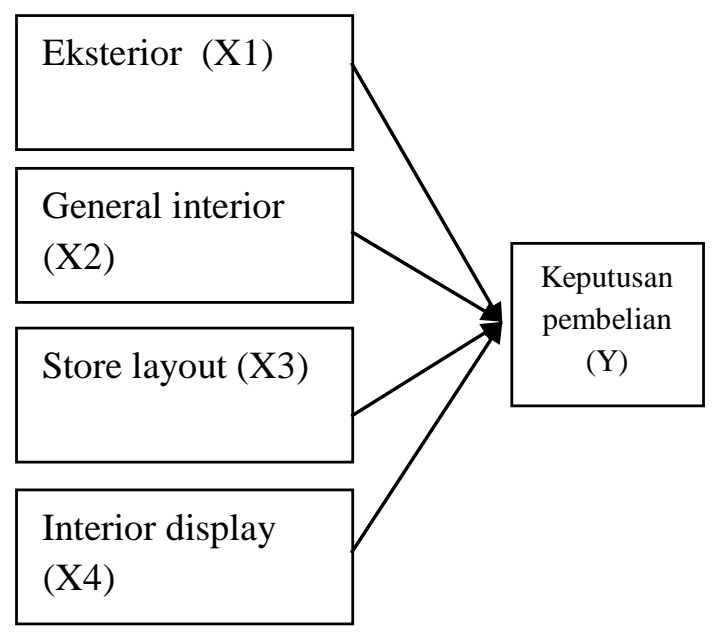

\section{Gambar 1 Paradigma Penelitian}

\section{Hipotesis}

H1: Eksterior berpengaruh terhadap Keputusan Pembelian konsumen.

$\mathrm{H} 2$ : General Interior berpengaruh terhadap Keputusan Pembelian konsumen.

H3: Store Layout berpengaruh terhadap Keputusan Pembelian konsumen

H4: Interior Display berpengaruh terhadap Keputusan Pembelian konsumen

\section{METODE PENELITIAN}

Dalam penelitian ini, penulis menggunakan penelitian survey, karena penelitian ini dilakukan dengan cara
Printed ISSN 2614-5391, e-ISSN 2614-2406 https://journal.uniku.ac.id/index.php/ijsm

mengambil sampel dari populasi dan menggunakan angket untuk mendapatkan informasi dari responden. Pernyataan ini sesuai dengan pendapat yang dikemukakan oleh Sugiyono (2008:7) "Penelitian survey adalah penelitian yang mengambil sampel dari populasi dengan menggunakan kuesioner".

Sedangkan metode yang digunakan dalam penelitian ini adalah "metode deskriftif analisis" yaitu penelitian yang bertujuan memberikan gambaran mengenai fakta-fakta, sifat serta pengaruh terhadap masing-masing variabel yang diteliti.

\section{Populasi dan Sampel}

Populasi dalam penelitian ini adalah konsumen Toserba Terbit Kuningan. Karena populasinya tidak bisa diketahui maka dalam penarikan sampelnya teknik pengambilan sampel yang dipakai oleh peneliti menggunakan metode Accidental sampling yaitu bentuk pengambilan sampel berdasarkan kebetulan. Dimana, siapa saja yang kebetulan bertemu dengan peneliti dan dianggap cocok menjadi sumber data yang akan menjadi sampel data yang akan menjadi sampel penelitian ini (Sugiyono,2008).

Karena Jumlah populasi ini terbatas dan sulit untuk diketahui secara pasti, maka penentuan jumlah sampel yang akan digunakan teknik pengambilan sempel menurut Rescoe (1975) memberikan pedoman penentuan ukuran sampel yang lebih besar dari 30 dan kurang lebih dari 500 sudah memadai bagi kebanyakan penelitian. Sehingga dalam penelitian ini dapat diambil sampel sebanyak 100 responden.

\section{Teknik Pengumpulan Data}

Teknik yang digunakan untuk memperoleh data yang diperlukan dengan cara "Kuesioner (angket)" adalah 
Indonesian Journal Of Strategic Management Vol 1, Issue 1, Februari 2018

sejumlah pertanyaan tertulis yang digunakan untuk memperoleh informasi dari responden dalam arti laporan tentang pribadinya atau hal-hal yang ia ketahui, Arikunto (2002:139). Teknik yang digunakan untuk memperoleh data yang diperlukan dengan cara kuesioner atau angket. Teknik pengumpulan data menggunakan skala interval dengan mengembangkan pertanyaan menghasilkan jawaban setuju - tidak setuju dalam rentang nilai 1-10.

\section{Uji Instrumen :}

\section{Uji Validitas}

Uji validitas digunakan untuk mengukur sah atau valid tidaknya suatu kuesioner. Suatu koesioner dikatakan valid jika pernyataan pada kuesioner mampu untuk mengungkap sesuatu yang akan diukur oleh kuesioner tersebut (Ghozali, 2001). Langkah selanjutnya adalah secara statistik, angka korelasi yang diperoleh dengan melihat tanda bintang pada hasil skor total, atau membandingkan dengan angka bebas korelasi nilai $r$ yang menunjukkan valid.

\section{Uji Reliabilitas}

Pengujian reliabilitas alat ukur yang bertujuan untuk memberikan hasil yang dapat diandalkan secara empiris dan dapat mengurangi tingkat kesalahan pada alat ukur. Hasil uji reliabilitas menunjukan bahwa nilai koefisien reliabilitas cronbach alpha lebih besar dari 0,60 (Nunally, 2012).

\section{Metode Analisis Data}

Analisis deskriptif digunakan untuk menggambarkan tentang ciri-ciri responden dan variabel penelitian. Selanjutnya untuk menetapkan peringkat dalam setiap variabel penelitian dapat dilihat dari perbandingan antar skor aktual dengan skor ideal. Skor aktual diperoleh melalui hasil perhitungan seluruh pendapat responden sesuai
Printed ISSN 2614-5391, e-ISSN 2614-2406 https://journal.uniku.ac.id/index.php/ijsm

klasifikasi bobot yang diberikan. Sedangkan skor ideal diperoleh melalui perolehan prediksi nilai tertinggi dikalikan dengan jumlah koesioner dikalikan jumlah responden.

\section{Uji Asumsi Klasik :}

\section{Uji Normalitas}

Dilakukan sebagai persyaratan untuk menggunakan statistik parametrik. Uji normalitas bertujuan untuk mengetahui apakah masing-masing variabel berdistribusi normal atau tidak.

\section{Uji Multikolinearitas}

Bertujuan menguji apakah dalam model regresi yang baik seharusnya tidak terjadi korelasi diantara variabel bebas jika variabel bebas berkorelasi maka variabel-variabel ini tidak ortogonal.
3.
Uji Heteroskedastisitas

Bertujuan untuk menguji apakah data dalam regresi terjadi ketidaksamaan varian dari residual satu pengamatan ke pengamatan lain.

4. Uji Autokorelasi

Untuk mengetahui ada tidaknya korelasi antara kesalahan pengganggu pada periode tertentu dengan kesalahan penggangu periode sebelumnya (Ghozali,2013).

\section{Analisis Regresi Linier Berganda}

Dalam penelitian ini analisis regresi linier berganda digunakan untuk mengetahui ada tidaknya pengaruh eksterior (X1) general interior (X2) store layout (X3) dan interior display (X4) terhadap keputusan pembelian (Y) konsumen Toserba Terbit Kuningan. Hubungan tersebut diukur dengan model persamaan sebagai berikut:

$\mathrm{Y}=\mathrm{a}+\mathrm{b} 1 \mathrm{X} 1+\mathrm{b} 2 \mathrm{X} 2+\mathrm{b} 3 \mathrm{X} 3+\mathrm{b} 4 \mathrm{X} 4+$ e

\section{Koefisien Determinasi}

Koefisien determinasi adalah kuadrat dari koefisien korelasi berganda yang dikalikan dengan 100\%. Dilakukan 
Indonesian Journal Of Strategic Management Vol 1, Issue 1, Februari 2018

untuk mengetahui seberapa besar variabel $\mathrm{X}$ mempunyai kontribusi atau ikut menentukan variabel Y.

\section{Uji Hipotesis}

Untuk mengetahui apakah variabel bebas yaitu elemen-elemen dari variabel store atmosphere adalah eksterior, general interior, store layout dan interior display secara persial dapat berpengaruh terhadap variabel terikat yaitu variabel keputusan pembelian konsumen (Y), maka perlu dilakukan pengujian hipotesis diatas, diperlukan uji t.

\section{HASIL DAN PEMBAHASAN \\ 4.1 HASIL \\ Uji Asumsi Klasik}

1. Uji Normalitas bertujuan untuk menguji apakah dalam model regresi, variabel penggangu atau residual memiliki distribusi normal. Seperti diketahui bahwa uji $t$ dan $F$ mengasumsikan bahwa nilai residual mengikuti distribusi normal. Pengujian menggunakan aplikasi program SPSS 20.0 berupa analisis One-Sample Kolmogorov-Smirnov Test. Dasar dalam pengambilan keputusan adalah jika Sig. (2-tailed) > 0,05 maka model regresi memenuhi asumsi normalitas.

Dari hasil perhitungan data pada tabel dapat diketahui bahwa uji normalitas data dengan menggunakan sampel $(n=100)$ sesuai dengan data sebelumnya, bahwa data tersebut menunjukan data berdistribusi normal, dari keseluruhan menunjukan angka lebih dari $0.05(\alpha)$ tarif signifikan yang ditentukan atau dengan kata lain data dari setiap variabel yaitu mengikuti data distribusi normal. Untuk hasil data uji normalitas dari variabel (X1) eksterior $0,075>0,05$, variabel (X2) general interior $0,138>0,05$, variabel (X3) store layout 0,268>0,05, variabel (X4) interior display $0,096>0,05$, dan
Printed ISSN 2614-5391, e-ISSN 2614-2406 https://journal.uniku.ac.id/index.php/ijsm

variabel (Y) keputusan pembelian 0,072 $>0,05$.

2. Uji Multikolinearitas, Cara untuk mendeteksi ada tidaknya multikolinearitas yaitu dengan melihat nilai VIF (Variance Inflatiaon Factor) dan nilai Tolerance. Model regresi dikatakan bebas dari multikolinearitas apabila nilai VIF $<10$, dan nilai Tolerance $>0,1$.

Tabel 4.1

Hasil Uji Multikolinearitas Coefficients $^{a}$

\begin{tabular}{|ll|r|r|}
\hline Model & \multicolumn{2}{|c|}{ Collinearity Statistics } \\
\cline { 3 - 4 } & & $\begin{array}{c}\text { Toleranc } \\
\mathrm{e}\end{array}$ & \multicolumn{1}{c|}{ VIF } \\
\hline \multirow{3}{*}{1} & X1 &, 620 & 1,614 \\
& X2 &, 711 & 1,407 \\
& X3 &, 681 & 1,468 \\
& X4 &, 554 & 1,804 \\
\hline
\end{tabular}

a. Dependent Variable: $Y$

Perhitungan nilai Variance Inflation Factor (VIF) menunjukan nilai VIF eksterior (X1) adalah 1,614, nilai VIF general interior (X2) adalah 1,407, nilai VIF store layout (X3) adalah 1,468 , nilai VIF interior display (X4) adalah 1,804. Ini menjukan tidak ada satu variabel independen pun yang memiliki nilai VIF $<$ 10. Jadi dapat disimpulkan bahwa tidak ada multikolinearitas antara variabel independen dalam model regresi. Hasil perhitungan juga menunjukan nilai Tolerance masingmasing variabel yaitu eksterior (X1) sebesar 0,620, general interior (X2) sebesar 0,711, store layout (X3) sebesar 0,681 dan interior display (X4) sebesar 0,554 . ini berarti menunjukan tidak ada variabel independen yang memiliki nilai Tolerance $>0,1$. Maka menurut nilai Tolerance tidak terjadi multikolinearitas dalam model regresi.

3. Uji Heteroskedastisitas digunakan untuk menguji apakah dalam 
Indonesian Journal Of Strategic Management Vol 1, Issue 1, Februari 2018

model regresi terjadi ketidaksamaan varian dari residual satu pengamatan ke pengamatan yang lain. Jika varian lain residual satu pengamatan ke pengamatan lain tetap, maka disebut homoskedastisitas dan jika berbeda disebut heteroskedastisitas.

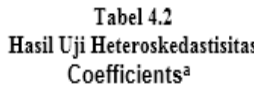

\begin{tabular}{|c|c|c|c|c|c|c|}
\hline \multirow[t]{2}{*}{ Mod } & & \multicolumn{2}{|c|}{$\begin{array}{c}\text { Unstandardized } \\
\text { Coefficients }\end{array}$} & \multirow{2}{*}{$\begin{array}{c}\begin{array}{c}\text { Standardized } \\
\text { Coefficients }\end{array} \\
\text { Beta }\end{array}$} & \multirow[t]{2}{*}{$\mathrm{T}$} & \multirow[t]{2}{*}{ Sig. } \\
\hline & & $B$ & Std. Error & & & \\
\hline \multirow{5}{*}{1} & (Constant) &,- 531 & 2,446 & &,- 217 &, 829 \\
\hline & $\mathrm{X} 1$ & , 104 &, 082 & 159 & 1,268 & 208 \\
\hline & $X 2$ &, 011 &, 084 & 016 & 133 & 894 \\
\hline & X3 &,- 114 &, 078 &,- 175 & $-1,463$ & 147 \\
\hline & $X_{4}$ & 140 &, 095 &, 195 & 1,470 & ,145 \\
\hline
\end{tabular}

Sumber: Output pengolahan data SPSS versi 20.0 for Windows

Hasil tampilan output dengan jelas menunjukan bahwa tidak ada satupun variabel independen yang signifikan secara statistik mempengaruhi variabel dependen nilai Absolut Unresidual. Nilai total (X1) eksterior sebesar 0,208, nilai total (X2) general interior sebesar 0,894, nilai total (X3) store layout sebesar 0,147 dan nilai total (X4) interior display sebesar 0,145. Hal ini terlihat jelas probabilitas signifikan diatas dengan tingkat kepercayaan 0,05 , jadi dapat disimpulkan model regresi tidak mengandung adanya heteroskedastisitas.

4. Uji Autokorelasi bertujuan untuk menguji apakah terdapat korelasi antara kesalahan pengganggu pada periode $t$ dengan kesalahan penggangu pada periode sebelumnya ( $\mathrm{t}-1)$ dalam model regresi. Jika terdapat korelasi maka model tersebut mengalami masalah autokorelasi. Model regresi yang baik adalah model yang bebas dari autokorelasi.
Printed ISSN 2614-5391, e-ISSN 2614-2406

https://journal.uniku.ac.id/index.php/ijsm

Tabel 4.4

Uji Durbin Watson

Model Summary

\begin{tabular}{l|r|r|r|r|r|}
\hline $\begin{array}{l}\text { Mod } \\
\text { el }\end{array}$ & $R$ & R Square & $\begin{array}{c}\text { Adjusted R } \\
\text { Square }\end{array}$ & $\begin{array}{r}\text { Std. Error of } \\
\text { the Estimate }\end{array}$ & Durbin-Watson \\
\hline 1 &, $819^{\mathrm{a}}$ &, 671 &, 657 & 1,77441 & 1,795 \\
\hline
\end{tabular}
a. Predictors: (Constant), $X 4, X 3, X 2, X 1$
b. Dependent Variable: $Y$

Berdasarkan tabel 4.29 menunjukan bahwa nilai DW hitung sebesar 1,795. Berdasarkan tabel DW dengan jumlah variabel independen $(\mathrm{k})=$ 4 dan jumlah observasi $(n)=100$, maka nilai batas bawah $(\mathrm{dL})=1,5922$ dan batas atas $(d U)=1,7582$. Jadi nilai DW berada diantara batas dU dan 4-dU $(1,7582<1,795<2,2418)$, sehingga tidak terjadi Autokorelasi.

\section{Koefisien Determinasi}

Analisis ini digunakan untuk mengetahui seberapa besar pengaruh bersama antara variabel independen $(\mathrm{X})$ dengan variabel dependen (Y). Dalam penelitian ini yaitu untuk mengetahui pengaruh eksterior, general interior, store layout dan interior display terhadap keputusan pembelian.

Tabel 4.4

Koefisien Determinasi (R2) Model Summary ${ }^{b}$

\begin{tabular}{l|r|r|r|r|}
\hline Model & R & R Square & $\begin{array}{c}\text { Adjusted R } \\
\text { Square }\end{array}$ & $\begin{array}{c}\text { Std. Error of } \\
\text { the Estimate }\end{array}$ \\
\hline 1 &, $819^{\mathrm{a}}$ &, 671 &, 657 & 1,77441 \\
\hline a. Predictors: (Constant), $\mathrm{X} 4, \mathrm{X} 3, \mathrm{X} 2, \mathrm{X} 1$ \\
a. Dependent Variable : $\mathrm{Y}$
\end{tabular}

Dari hasil perhitungan analisis dengan menggunakan SPSS for windows 20.0, dapat diketahui bahwa $\mathrm{R}$ square $\left(\mathrm{r}^{2}\right)$ yaitu sebesar 0,671, maka dapat diketahui pengaruh bersama eksterior, general interior, store layout dan interior display terhadap keputusan pembelian : 0,671 x $100 \%=67,1 \%$.

Dengan hasil ini maka dapat disimpulkan bahwa 67,1 \% keputusan 
Indonesian Journal Of Strategic Management Vol 1, Issue 1, Februari 2018
Printed ISSN 2614-5391, e-ISSN 2614-2406 https://journal.uniku.ac.id/index.php/ijsm pembelian dipengaruhi oleh faktor eksterior, general interior, store layout dan interior display sedangkan 32,9\% dipengaruhi oleh faktor lain yang tidak diteliti oleh peneliti.

\section{Analisis Regresi Linier Berganda}

1. Konstanta sebesar 1,398 menyatakan bahwa jika tidak ada eksterior, general interior, store layout dan interior display, maka keputusan pembelian 1,398.

2. Koefisien regresi 0,244 menyatakan bahwa setiap perubahan satu satuan point nilai eksterior akan menaikan keputusan pembelian sebesar 0,244 .

3. Koefisien regresi 0,352 menyatakan bahwa setiap perubahan satu satuan pint nilai general interior akan menaikan keputusan pembelian sebesar 0,352.

4. Koefisien regresi 0,212 menyatakan bahwa setiap perubahan satu satuan point nilai store layout akan menaikan keputusan pembelian sebesar 0,212 .

5. Koefisien regresi 0,414 menyatakan bahwa setiap perubahan satu satuan point nilai interior display akan menaikan keputusan pembelian sebesar 0,414.

Melihat uji $\mathrm{F}$ terlihat bahwa persamaan regresi bermakna (sig 0.05) artinya persamaan regresi ini dapat digunakan untuk memprediksi keputusan pembelian.

\section{Uji Signifikan}

\begin{tabular}{|c|c|c|c|c|c|}
\hline $\begin{array}{l}\text { Selanjutny } \\
\text { kebermak } \\
\text { tersebut m }\end{array}$ & $\begin{array}{l}\text { an } \\
\text { ra dilak }\end{array}$ & $\begin{array}{l}\text { uk } \\
\text { enga } \\
\text { kan } \\
\text { abel } 4.5 \\
\text { Signifika } \\
\text { IOVA }^{\text {b }}\end{array}$ & $\begin{array}{l}\text { me } \\
\text { uji F. }\end{array}$ & $\begin{array}{l}\text { Igeta } \\
\text { gersa }\end{array}$ & \\
\hline Model & $\begin{array}{l}\text { Sum of } \\
\text { Squares }\end{array}$ & $\overline{D f}$ & Mean Square & $\mathrm{F}$ & Sig. \\
\hline Regression & 609,639 & 4 & 152,410 & 48,406 &, $000^{\circ}$ \\
\hline Residual & 299,111 & 95 & 3,149 & & \\
\hline Total & 908,750 & 99 & & & \\
\hline
\end{tabular}

Dari uji anova atau $\mathrm{F}$ test didapat $\mathrm{F}$ sebesar 48,406 dengan signifikansi 0,000 . Artinya pengaruh bersama antara eksterior, general interior, store layout dan interior display terhadap keputusan pembelian bermakna atau signifikan.

\section{Uji Hipotesis :}

1. Berdasarkan hasil analisis, diperoleh nilai $t_{\text {hitung }}$ sebesar $(2,976)>\mathrm{t}$ tabel $(1,660)$ dan sig < 0,05 yaitu 0,004 . Oleh karena itu, $\mathrm{H}_{0}$ ditolak dan $\mathrm{H}_{1}$ diterima. Artinya ada pengaruh antara eksterior terhadap keputusan pembelian.

2. Berdasarkan hasil analisis, diperoleh nilai thitung sebesar $(4,169)>\mathrm{t}$ tabel $(1,660)$ dan sig $<0,05$ yaitu 0,000 . Oleh karena itu, $\mathrm{H}_{0}$ ditolak dan $\mathrm{H}_{1}$ diterima. Artinya ada pengaruh antara general interior terhadap keputusan pembelian.

3. Berdasarkan hasil analisis, diperoleh nilai $t_{\text {hitung }}$ sebesar $(2,720)>\mathrm{t}$ tabel $(1,660)$ dan sig $<0,05$ yaitu 0,008 . Oleh karena itu, $\mathrm{H}_{0}$ ditolak dan $\mathrm{H}_{1}$ diterima. Artinya ada pengaruh antara store layout terhadap keputusan pembelian.

4. Berdasarkan hasil analisis, diperoleh nilai thitung sebesar $(4,349)>\mathrm{t}$ tabel $(1,660)$ dan sig $<0,05$ yaitu 0,000 . Oleh karena itu, $\mathrm{H}_{0}$ ditolak dan $\mathrm{H}_{1}$ diterima. Artinya ada pengaruh antara interior display terhadap keputusan pembelian.

\subsection{PEMBAHASAN}

1. Gambaran elemen store atmosphere (eksterior, general interior, store layout, interior display) dan keputusan pembelan.

Berdasarkan hasil analisis deskriptif tanggapan responden mengenai eksterior didapatkan rata-rata sebesar $71,3 \%$, general interior $68,55 \%$, store layout 
Indonesian Journal Of Strategic Management Vol 1, Issue 1, Februari 2018

$71,05 \%$, interior display $68,57 \%$, hal ini menggambarkan bahwa responden menganggap eksterior, general interior, store layout, interior display yang dimiliki Toserba Terbit Kuningan telah baik. Hasil analisis deskriptif tanggapan responden mengenai keputusan pembelian konsumen didapatkan ratarata sebesar 65,1\%, hal ini menggambarkan bahwa responden menganggap keputusan pembelian konsumen yang dimiliki Toserba Terbit Kuningan cukup baik.

2. $\mathrm{H}_{1}$ : Eksterior berpengaruh positif dan signifikan terhadap keputusan pembelian.

Berdasarkan hasil analisis pengaruh variabel eksterior terhadap keputusan pembelian diperoleh hasil bahwa variabel eksterior dapat memprediksi terhadap keputusan pembelian secara positif. Nilai signifikan yang diperoleh sebesar 0,004 mengandung arti bahwa hipotesis diterima. Apabila dilihat dari uji $t$ diperoleh bahwa nilai sig 0,004. Dengan demikian diketahui bahwa sig $<0,05$ atau $0,004<0,05$. Artinya bahwa hipotesis yang telah dirumuskan sebelumnya menyatakan bahwa "eksterior berpengaruh terhadap keputusan pembelian" diterima atau terbukti, maka $\mathrm{H}_{0}$ ditolak dan $\mathrm{H}_{1}$ diterima. Hasil penelitian ini juga sesuai hasil penelitian Dessyana (2013) diperoleh bahwa hasil eksterior secara persial berpengaruh positif dan signifikan terhadap keputusan pembelian.

3. $\mathrm{H}_{2}$ : General interior berpengaruh positif dan signifikan terhadap keputusan pembelian.

Berdasarkan hasil analisis pengaruh variabel general interior terhadap keputusan pembelian diperoleh bahwa variabel general interior dapat
Printed ISSN 2614-5391, e-ISSN 2614-2406 https://journal.uniku.ac.id/index.php/ijsm

memprediksi terhadap keputusan pembelian secara positif. Nilai signifikan yang diperoleh sebesar 0,000 mengandung arti bahwa hipotesis diterima. Apabila dilihat dari uji $\mathrm{t}$ diperoleh bahwa nilai sig 0,000. Dengan demikian diketahui bahwa sig $<0,05$ atau $0,000<0,05$. Artinya bahwa hipotesis yang telah dirumuskan sebelumnya menyatakan bahwa "general interior berpengaruh terhadap keputusan pembelian" diterima atau terbukti, maka $\mathrm{H}_{0}$ ditolak dan $\mathrm{H}_{1}$ diterima. Hasil penelitian ini juga sesuai hasil penelitian Dessyana (2013) dan Yuliandi (2014) yang menyimpulkan bahwa general interior berpengaruh positif dan signifikan terhadap keputusan pembelian.

4. $\mathrm{H}_{3}$ : Store layout berpengaruh positif dan signifikan terhadap keputusan pembelian.

Berdasarkan hasil analisis pengaruh variabel store layout terhadap keputusan pembelian diperoleh bahwa variabel store layout dapat memprediksi terhadap keputusan pembelian secara positif. Nilai signifikan yang diperoleh sebesar 0,008 mengandung arti bahwa hipotesis diterima. Apabila dilihat dari uji $t$ diperoleh bahwa nilai sig 0,008. Dengan demikian diketahui bahwa sig $<0,05$ atau $0,008<0,05$. Artinya bahwa hipotesis yang telah dirumuskan sebelumnya menyatakan bahwa "store layout berpengaruh terhadap keputusan pembelian" diterima atau terbukti, maka $\mathrm{H}_{0}$ ditolak dan $\mathrm{H}_{1}$ diterima.

Hasil penelitian ini juga sesuai hasil penelitian Dessyana (2013) dan Yuliandi (2014) yang menyimpulkan bahwa store layout berpengaruh positif dan signifikan terhadap keputusan pembelian. 
Indonesian Journal Of Strategic Management Vol 1, Issue 1, Februari 2018

5. $\mathrm{H}_{4}$ : Interior display berpengaruh positif dan signifikan terhadap keputusan pembelian

Berdasarkan hasil analisis pengaruh variabel interior display terhadap keputusan pembelian diperoleh bahwa variabel interior display dapat memprediksi terhadap keputusan pembelian secara positif. Nilai signifikan yang diperoleh sebesar 0,000 mengandung arti bahwa hipotesis diterima. Apabila dilihat dari uji $\mathrm{t}$ diperoleh bahwa nilai sig 0,000. Dengan demikian diketahui bahwa sig $<0,05$ atau $0,000<0,05$. Artinya bahwa hipotesis yang telah dirumuskan sebelumnya menyatakan bahwa "interior display berpengaruh terhadap keputusan pembelian" diterima atau terbukti, maka $\mathrm{H}_{0}$ ditolak dan $\mathrm{H}_{1}$ diterima. Hasil penelitian ini juga sesuai hasil penelitian Dessyana (2013) dan Yuliandi (2014) yang menyimpulkan bahwa interior display berpengaruh positif dan signifikan terhadap keputusan pembelian.

\section{KESIMPULAN DAN SARAN Kesimpulan}

Berdasarkan penelitian dan pembahasan yang telah dikemukakan sebelumnya, maka dapat ditarik kesimpulan sebagai berikut :

1. Hasil analisis deskriptif Eksterior, General Interior, Store Layout, dan Interior Display yang dimiliki Toserba Terbit Kuningan telah baik, sedangkan analisis deskriptif Keputusan Pembelian konsumen Toserba Terbit Kuningan menunjukan hasil telah cukup baik.

2. Elemen dari Store Atmosphere yaitu Eksterior berpengaruh positif dan signifikan terhadap keputusan pembelian pada Toserba Terbit Kuningan, artinya konsumen ketika akan melakukan pembelanjaan di Toserba Terbit
Printed ISSN 2614-5391, e-ISSN 2614-2406 https://journal.uniku.ac.id/index.php/ijsm

memperhatikan bagian luar toko terlebih dahulu apabila konsumen tertarik berbelanja pada Toserba Terbit maka keputusan pembelian konsumen akan meningkat.

3. Elemen dari Store Atmosphere yaitu General Interior berpengaruh positif dan signifikan terhadap keputusan pembelian pada Toserba Terbit Kuningan, artinya konsumen ketika akan melakukan pembelanjaan di Toserba Terbit memperhatikan bagian dalam toko terlebih dahulu apabila konsumen lebih nyaman berada di Toserba Terbit maka keputusan pembelian konsumen akan meningkat.

4. Elemen dari Store Atmosphere yaitu Store Layout berpengaruh positif dan signifikan terhadap keputusan pembelian pada Toserba Terbit Kuningan, artinya konsumen ketika akan melakukan pembelanjaan di Toserba Terbit memperhatikan tata letak toko terlebih dahulu apabila konsumen lebih mudah untuk mencari produk yang diinginkan maka keputusan pembelian konsumen akan meningkat.

5. Elemen dari Store Atmosphere yaitu Interior Display berpengaruh positif dan signifikan terhadap keputusan pembelian pada Toserba Terbit Kuningan, artinya konsumen ketika akan melakukan pembelanjaan di Toserba Terbit memperhatikan penataan produk terlebih dahulu apabila konsumen lebih mudah untuk mencari produk maka keputusan pembelian konsumen akan meningkat.

\section{Saran}

Berdasarkan penelitian yang telah diperoleh dalam penelitian ini, maka peneliti akan memberikan saran yang diharapkan akan menjadi masukan dan bahan pertimbangan bagi perusahaan Toserba Terbit, saran-saran tersebut adalah sebagai berikut : 
Indonesian Journal Of Strategic Management Vol 1, Issue 1, Februari 2018

1. Diharapkan Toserba Terbit Kuningan untuk terus meningkatkan eksterior-nya terutama untuk papan nama. Hal ini dapat dilakukan dengan memberikan papan nama yang besar dengan lebih menarik dan inovatif agar mudah dilihat serta dapat menarik pelanggan untuk berbelanja di Toserba Terbit Kuningan.

2. Diharapkan Toserba Terbit Kuningan untuk terus meningkatkan general interior-nya terutama untuk aroma ruangan dan suhu udara. Hal ini dapat dilakukan dengan menambah pengharum ruangan dan menambahkan AC supaya udara di ruangan sejuk sehingga konsumen nyaman berada di Toserba Terbit.

3. Diharapkan Toserba Terbit Kuningan untuk terus meningkatkan store layout-nya terutama untuk sistem pengelompokan produk. Hal ini dapat dilakukan dengan perampingan pengelompokan produk sehingga konsumen mudah untuk mencari produk yang diinginkan.

4. Diharapkan Toserba Terbit Kuningan untuk terus meningkatkan interior display-nya terutama untuk penataan produk dalam rak. Hal ini dapat dilakukan dengan cara penataan produk dalam rak yang tertata rapih supaya konsumen lebih mudah untuk mencari produk dalam rak.

\section{DAFTAR PUSTAKA}

APRINDO. Media Data-Aprindo. Jakarta. Asosiasi Pengusaha Ritel Indonesia

Amirullah. 2002. Perilaku Konsumen. Graha Ilmu. Yogyakarta

Arikunto, Suharsimi. 2002. Prosedur penelitian : Suatu Pendekatan Praktik. Jakarta : Rineka Cipta.
Printed ISSN 2614-5391, e-ISSN 2614-2406 https://journal.uniku.ac.id/index.php/ijsm

Berman, Barry \& Evans, Joel R. 2010. Retail Management (11 th ed). New Jersey :Prentice Hall.

Ghozali, Imam, 2001. Aplikasi Analisis Multivarete Dengan Program SPSS. Semarang: Badan Penerbit Universitas Diponegoro.

Ghozali, Imam. 2013. Analisis Multivariate dengan Program SPSS. Semarang: Badan Penerbit Universitas Diponegoro

Kotler, dan Amstrong, (2015). PrinsipPrinsip Pemasaran. Edisi 12, Jilid 1. Erlangga. Jakarta.

Kotler, Philip dan Kevin L. Keller. 2009. Manajemen Pemasaran, Edisi 12, Jilid 1. Alih Bahasa: Bob Sabran. Erlangga, Jakarta.

Meldarinda, Resti. (2010). Pengaruh Store Atmosphere terhadap Minat Beli Konsumen pada Resort Cafe Atmosphere Bandung. Jurnal Bisnis dan Ekonomi. Vol. 17. No. 2.

Muhamad, Fuad.. Pengaruh Atmosphere dan Perilaku Pembelian Konsumen di Toko Buku Gramedia Malang. Jurnal Bisnis dan Ekonomi. ISSN: 2085-0972

Nofiawati \& Beli Yuliandi. (2014). Pengaruh Store Atmosphere Terhadap Keputusan Pembelian Pada Outlet Nyesnyes Palembang. Jurnal Manajemen dan Bisnis Sriwijaya Vol.12 N0.1 Maret 2014.

Puspitasari, Devi, dkk 2012. Membuka Usaha Eceran/Ritel (Exspansion Store Opening). Jakarta : Penerbit Inti Prima Promosindo.

Roscue, J.T. 1975. Fundamental Research Statistic for The Behavior Sciencess. (2nd,ed), Holt, Rinehart and Winston. New York.

Schiffman, Leon dan Kanuk Leslie Lazar. 2010. Perilaku Konsumen. Jakarta : PT Indeks.

Septia, Heryana. (2014). Pengaruh Store Atmosphere dan Gaya Hidup Terhadap 
Indonesian Journal Of Strategic Management Vol 1, Issue 1, Februari 2018

Keputusan Pembelian Konsumen pada Outlet The Secret Bandung. Jurnal manajemen Bisnis.
Printed ISSN 2614-5391, e-ISSN 2614-2406

https://journal.uniku.ac.id/index.php/ijsm 